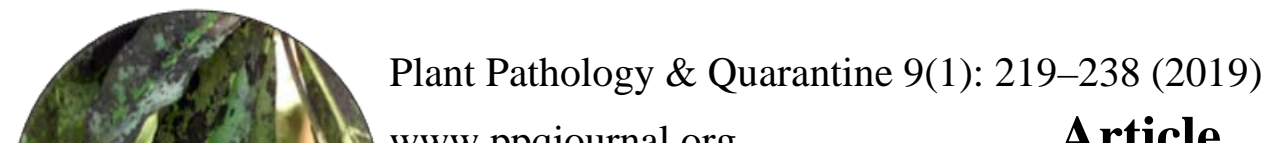

ISSN 2229-2217 www.ppqjournal.org

Article

Doi 10.5943/ppq/9/1/20

\title{
The Genus Cronartium Revisited
}

\section{Wijesinghe $\mathrm{SN}^{1,2}$, McKenzie $\mathrm{E}^{3}$, Wanasinghe $\mathrm{DN}^{4}$, Boonmee $\mathrm{S}^{1,2}$ and Jayawardena $\mathrm{RS}^{1,2}$}

${ }^{1}$ Center of Excellence in Fungal Research, Mae Fah Luang University, Chiang Rai 57100, Thailand

${ }^{2}$ School of Science, Mae Fah Luang University, Chiang Rai 57100, Thailand

${ }^{3}$ Manaaki Whenua-Landcare Research, Private Bag 92170, Auckland Mail Centre, Auckland 1142, New Zealand

${ }^{4}$ Key Laboratory of Biodiversity and Biogeography, Kunming Institute of Botany, Chinese Academy of Sciences, Kunming 650201, China

Wijesinghe SN, McKenzie E, Wanasinghe DN, Boonmee S, Jayawardena RS 2019 - The Genus Cronartium Revisited. Plant Pathology \& Quarantine 9(1), 219-238, Doi 10.5943/ppq/9/1/20

\begin{abstract}
Cronartium is a prominent rust pathogen (Pucciniales, Basidiomycota). The type species of the genus was Cronartium asclepiadeum, which is currently synonymized under C. pini. Cronartium species infect branches, cones and stems of Pinus species, which are economically and ecologically valued crops in many countries in North and Central America, Asia and Europe. Cronartium species show host specificity alternating between two unrelated hosts such as Pinus and Ribes species. In this macrocyclic, heteroecious lifecycle, the five different spore stages are produced. They are the causal agent of numerous blister rust diseases such as cone rust disease, gall rust disease and limb rust disease on pine forests worldwide. Mainly, Cronartium comptoniae causes sweet fern blister rust, $C$. ribicola causes white pine blister rust, C. comandrae causes comandra blister rust, C. pini (=Peridermium pini) causes resin-top disease, $C$. quercuum causes gall rust disease in pine-oaks, $C$. arizonicum causes limb rust disease and $C$. strobilinum and $C$. conigenum cause cone rust disease. All species of Endocronartium have been synonymized and transferred to Cronartium. The updated phylogenetic analysis for the genus Cronartium is performed based on ITS sequence data from GenBank. This study is focused on morphology, phylogeny, pathogenicity and mitigation methods as well as future directions for research on the genus Cronartium.
\end{abstract}

Key words - Five spore stages - pathogens - rust diseases

\section{Introduction}

Rusts are obligate parasites of plants, including many economically valuable plants such as bean, coffee, peanut, wheat and others (Littlefield \& Heath 1979, Zuluaga et al. 2011). They were identified as autoecious species in carboniferous period in two original hosts, ferns and mosses (Millar \& Kinloch 1989). After heteroecism evolved, they became specialized on their primary hosts, but required a secondary, usually unrelated host plant on which to complete their life cycle. In the past, ancient angiosperms and old pine hosts were shared by rusts including Cronartium comptoniae, C. flaccidum (=C. pini), C. occidentale, C. quercuum and C. ribicola (Millar \& Kinloch 1989). Each Cronartium species has high pathogenic variability on both pine and the alternate host (Powers 1982).

Cronartium species have a heteroecious life cycle. Most Cronartium spp. alternate between aecial (primary) host and telial (secondary) hosts. Mainly, Cronartium spp. affect Pinus spp. 
(Pinaceae) as aecial hosts. Spermatia and aeciospores are formed on the aecial host. Main telial hosts of Cronartium spp. are Ribes spp. and different dicotyledonous hosts (Fagaceae, Grossulariaceae, Myricaceae, Orobanchaceae, Santalaceae and Scrophulariaceae). For example, Cronartium conigenum, and C. strobilinum infect Quercus spp. while C. orientale and C. quercuum affect Castanea spp., Castanopsis spp. and Quercus spp. (EFSA Panel on Plant Health et al. 2018). Both urediniospores and teliospores are formed on the telial hosts. The aeciospore stage, in particular, is the economically damaging stage. The infection and production of aecia leads to different symptoms according to the Cronartium species on host tissues such as, branch and stem dieback, cankers, deformity, galls and cone death (EFSA Panel on Plant Health et al. 2018), leading to lower quantity and poorer quality timber yields.

\section{Classification}

Phylum Basidiomycota contains rusts under class Pucciniomycetes, order Pucciniales (previously known as Urediniomycetes and Uredinales). There are 13 families within Urediniomycetes separated according to telial morphology, spermogonial and aecial type, basidiospores and uredinial characteristics (Cummins \& Hiratsuka 2003, Kolmer et al. 2009). The genus Cronartium was described by Fries (1815) with Cronartium asclepiadeum (Willd.) Fr. as the type species of the genus. The type species was later synonymized under $C$. flaccidum (Hiratsuka (1995) and currently synonymized as Cronartium pini (Species Fungorum 2019). Cronartium is the only genus of family Cronartiaceae (Maier et al. 2003). Sydow \& Sydow (1915) accepted 22 Cronartium species while Peterson (1973) documented 36 species according to the telial morphology. Regarding the spermogonia types and other morphological features, 19 species have been transferred to Cianothrix, Crossopsora, Didymopsora and Endophylloides (Hiratsuka 1995). Hiratsuka (1995) recognized 16 Cronartium species. With complexity of species level, known closely related species of Cronartium are divided into five species complexes viz. Cronartium coleosporioides, C. comandrae, C. flaccidum (=C. pini), C. ribicola and C. quercuum (Hiratsuka 1995).

Ninety-two species epithets are listed under Cronartium (Index Fungorum 2019). Species which show a genetic similarity to Cronartium, but exclude autoecious and endocyclic characters, were included in Endocronartium (Aime et al. 2018). Endocronartium was established by Hiratsuka (1969) using spore and germ tube characteristics (Hiratsuka 1995, 1969, Aime et al. 2018). Endocronartium harknessii, the type species for Endocronartium is the main causal agent of western gall rust (Aime et al. 2018). Including Endocronartium harknessii, E. sahoanum var. hokkaidoense, E. sahoanum var. sahoanum (synonymized as Cronartium harknessii, C. kurilense, C. sahoanum, respectively) all species of Endocronartium have been synonymized and moved to Cronartium (Aime et al. 2018, EFSA Panel on Plant Health et al. 2018). Endocronartium pini and E. yamabense are currently known as C. pini and C. yamabense, respectively (Hantula et al. 2002, Aime et al. 2018, Index Fungorum 2019).

\section{Geographical distribution}

In past, Cronartium species are naturally limited to the Northern hemisphere in Asia, Europe and North America. Until 1900, few Cronartium rust diseases are highlighted in United States, North America. They are eastern gall rust disease (C. cerebrum), southern fusiform rust disease (C. fusiforme) and western gall rust disease (C. coleosporiodes) (Smith 1970). Cronartium ribicola is a well-studied rust, related to white pines, currants and gooseberries trees which are distributed in Asia, Europe and North America (Geils et al. 2010). The first record of C. ribicola was from Western Russia (Transcontinental country in Eastern Europe and North Asia) in 1856 (Stewart 1906, Hummer 2000). According to Hummer (2000) C. ribicola probably originated in central Eurasia (all of Eastern Europe and North Asia) (Leppik 1967, Spaulding 1929). Further, he mentioned, it may spread from east of the Ural Mountains (from north to south through Western Russia) through central Siberia (Russia) reaching to the Pacific coast of Asia in the east and southwards to the Himalayas (Asia). Also, Stewart (1906) has mentioned that C. ribicola may have been inadvertently imported from 
Russia to Eastern Europe. In the same time, in 1906, C. ribicola was observed in Germany (Western Europe) and in 1921 it was found in British Columbia on a shipment of white pines from France. In $20^{\text {th }}$ century, C. ribicola spread from its native Siberia (Leppik 1970) into Europe and became widespread in Northern and Western Europe. Some species have been introduced to new areas in North America from Europe. For example, C. ribicola was native to Asia and Southern Europe affecting white pines (Zambino et al. 2005, Kolmer et al. 2009, Kaitera \& Hiltunen 2012, Brar et al. 2015). It was introduced to Eastern and Western North America with imported pine seedlings from Europe in 1890s (Smith 1970, Powers 1982, McDonald \& Hoff 2001, Brar et al. 2015). Cronartium ribicola was spread to Northern Europe also (Kaitera \& Hiltunen 2011, 2012).

Cronartium pini (as C. flaccidum and Peridermium pini) is the common native pine stem rust pathogen in Asia and Europe (Hiratsuka et al. 1992, Kaitera et al. 2011) and Mediterranean countries (Moriondo 1975, Kasanen 2001, Kaitera et al. 2018). Hiratsuka (1995) mentioned that the European and Asian forms of C. pini can be found in China, Japan and Russia also. In North America C. comandrae, C. coleosporioides and C. comptoniae were identified (Hiratsuka et al. 1992). Cronartium harknessii (western pine gall rust) is prominent in North America while C. kurilense and C. sahoanum are prominent in Russia and Japan (EFSA Panel on Plant Health et al. 2018).

\section{Importance as pathogens}

Cronartium species have a deleterious effect in forest pine trees which have great ecological value. Cronartium ribicola is an invasive alien fungal species, which causes white pine blister rust disease (Powers 1982, Ma et al. 2019). Five-needle pines (Pinus spp.) are main primary hosts and currant and gooseberries are the secondary hosts (Kolmer et al. 2009, Geils et al. 2010). It mostly infects Pinus cembra (Pawsey 1963, Kaitera \& Hiltunen 2012) also other most important hard pine species Pinus lambertiana (sugar pine), P. monticola (western white pine) and P. strobus (eastern white pine) and other five-needle pines (Gäumann 1959) in North America where it was introduced from Europe in 1906 (Bergeron et al. 2019, Schoettle et al. 2019). By the 1950s it had spread to most of the commercial white pine regions in North America (Maloy 2003).

In Finland (Europe) 1800s, C. ribicola was first reported on exotic five-needle pines and in Britain on Pinus strobus, currants and gooseberries in 1892 (Liro 1908, O’Hara et al. 2010). Also, they have affected other less commercially important five-needle white pines i.e. Pinus albicaulis (white bark pine), Pinus flexilis (limber pine) (Maloy 2003). In Europe, they damage Pinus palustris subsp. palustris and trees in Apocynaceae and Tropaeolaceae families (Kaitera \& Hiltunen 2012, Singleton \& Oblinger 2017). This pathogen also infects Ribes sp. (Grossulariaceae) and Pedicularis (Orobanchaceae) in Asia, and Loasaceae in North America (Kaitera \& Hiltunen 2012). Ribes nigrum is most susceptible to C. ribicola in Finland (Kaitera \& Hiltunen 2012). Cronartium species naturally sporulate on Euphrasia stricta, Melampyrum arvense, Odontites vulgaris, Ribes nigrum, R. rubrum, $R$. uva-crispa and Vincetoxicum hirundinaria. Other than natural habitats they can be sporulated on several garden plants such as Asclepias, Paeonia, Tropaeolum, Vincetoxicum and Papaver in Germany of central Europe (Kaitera et al. 2018).

Cronartium pini infects on two-needle pines with significant economic loss throughout Europe and Asia (Kaitera \& Hiltunen 2012, Kaitera et al. 2018). This is listed as a harmful organism (as C. flaccidum) in different countries such as Colombia, New Zealand, and Taiwan (Sullivan 2010). It is a host-alternating fungus which has reported for resin top disease (Scots pine blister rust) in young Scots pine (Pinus sylvestris) with dead tops of green crowns (Kasanen 2001, Kaitera et al. 2018). Cronartium pini affects needles of pine by basidiospores and the aecia formation is prolonged for several years. The alternate hosts of Cronartium pini are in many angiosperm genera: Asclepias, Castilleja, Euphrasia, Gentiana, Grammatocarpus, Impatiens, Loasa, Melampyrum, Nemesia, Paeonia, Papaver, Pedicularis, Schizanthus, Tropaeolum, Verbena, Veronica, and Vincetoxicum (Kaitera et al. 2015, 2018). Melampyrum spp. are the main alternate hosts for C. pini and it spreads in natural pine forests via Vincetoxicum hirundinaria in Southern Europe and Melampyrum sylvaticum in Northern Europe (Kaitera \& Hiltunen 2011, 2012, Kaitera et al. 2015, 2018). Cronartium pini does not infect five-needle pines or Ribes spp. (Kaitera \& Nuorteva 2006). The 
autoecious C. pini is also causes resin top disease especially on Pinus mugo (Kasanen 2001, Kaitera \& Nuorteva 2008).

Cronartium comandrae causes comandra blister rust in Pinus banksiana in Canada, $P$. contorta (lodgepole pine), $P$. ponderosa (ponderosa pine) and P. sylvestris (European Scots pine) plantations in North America (Jacobi et al. 1993, 2002, Reich \& John 2018). Also, European maritime pine ( $P$. pinaster), Austrian pine ( $P$. nigra) and mountain pine ( $P$. mugo) have been reported to be vulnerable in North America. This pathogen is widely distributed in Western USA and Canada (Jacobi et al. 2002). Severe impacts of comandra blister rust occur where aecial and telial hosts grow near to each other (Jacobi et al. 1993). The aecial hosts of C. comandrae are two- and three-needled Pinus spp. in North America. The common telial host is Comandra umbellata (pale comandra) in Northern Montana and Canada, and Geocaulon lividum (northern comandra) in Canada (Jacobi et al. 2002). Comandra rust cankers can girdle the pine stem and kill branches, crown and the entire tree with a growth loss, deformation and lower seed production (Jacobi et al. 2002).

Sweet fern blister rust (C. comptoniae) is a serious canker disease that girdles and kills native two and three needle Pinus spp. in North America (Smeltzer \& French 1981, Horst 2008). The cankers can appear on small plants with elongated swellings. Pinus banksiana, P. contorta, P. muricata, $P$. ponderosa, $P$. resinosa, $P$. rodiata and $P$. taeda are main native pine hosts. Sweet fern (Comptonia peregrina) and sweet gale (Myrica gale) are main alternate hosts in North America (Pawsey 1974, Smeltzer \& French 1981). European pine species planted in North America such as $P$. sylvestris and P. nigra are more susceptible to sweet fern rusts (Pawsey 1974).

Stalactiform blister rust, $C$. coleosporioides also induces perennial cankers on two and three needle pine trees such as Pinus contorta, P. banksiana and P. ponderosa in North America (Mordue \& Gibson 1978, Nevill et al. 1990). Van der Kamp (1994) also reported C. coleosporioides infections on $P$. contorta trees mostly occurring on branches around $2 \mathrm{~m}$ above the ground. Indian paintbrush (Castilleja spp.) and members of figwort family (Scrophulareacea) are main alternate hosts for stalactiform rust. This pathogen affects lumber content, and growth rate of hosts. Hiratsuka et al. (1988) revealed C. coleosporioides is less aggressive than C. comandrae and C. comptoniae in girdling pine trees.

Pine-oak rusts infect oak hosts and also stems, branches and cones of pines and are widely distributed in North America. The severity of parasitism by pine-oak rusts depends on their alternate hosts and it is difficult to identify on oak hosts (Vogler 2008). Cronartium quercuum f.sp. banksianae, C. quercuum f.sp. echinatae and C. quercuum f.sp. virginianae are pine-oak rusts which cause eastern gall rust disease. Jack pine, shortleaf pine and Virginia pine are the primary hosts for these rusts, respectively (Vogler 2008). Cronartium quercuum f.sp. fusiforme is a pine-oak rust which causes fusiform rust on shortleaf pine in Southeastern US and Southern North America (Vogler 2008, Kaneko 2000). Cronartium fusiforme is recognized as a significant disease of two needle pines in Asia, North America (Kaitera \& Nuorteva 2008, Sniezko et al. 2014). Cronartium harknessii (Peridermium harknessii) causes western gall rust disease of hard pines in North America and is not present in southern hemisphere (Allen et al. 1998). The aeciospores of $C$. harknessii produce globose galls on branches and stems of host trees 1-2 years after infection (Allen et al. 1998). Cronartium orientale causes Asian pine-oak rust disease (Kaneko 2000). The spermogonia and aecia of $C$. orientale are produced on hard pine trees while uredinial and telial forms are on oak trees (Kaneko 2000). Cronartium strobilinum and C. conigenum are other pine-oak rusts reported in some Pinus spp. such as longleaf, slash pine and ponderosa pines (Vogler 2008). Cronartium appalachianum, Virginia pine blister rust infects $P$. virginiana as primary host by girdling the pine bark lesions (Vogler \& Bruns 1998, Horst 2008, Ratliff et al. 2015) with Buckleya distichophylla as the alternate host (Horst 2008, Ratliff et al. 2015). Cronartium arizonicum causes limb rust disease mainly on ponderosa pines in Arizona (Fairweather et al. 2006). Initially, C. arizonicum attacks needle-bearing twigs to enter the main stem of pine trees, and damage the branches. Castilleja spp. are main alternate hosts for C. arizonicum (Fairweather et al. 2006).

Cronartium ribicola creates a huge ecological devastation by killing economically important hosts in many countries, thereby affecting plant economy. Singleton \& Oblinger (2017) reported that 
white pine trees have great economic value compared to other crops of Warm Springs Reservation (WSR) in Western North America. The annual economic loss caused by white pine blister rust in Western North America has been estimated at US\$ 450 million (Hamelian 2012). Fusiform rusts (Cronartium quercuum f.sp. fusiforme) which infect economically valuable loblolly pine ( $P$. taeda) and slash pine (P. elliottii) and P. palustris in Southern and Southeastern US (Sniezko et al. 2014) cause over \$140 million annual estimated economic losses (Hamelian 2012, Sniezko et al. 2014).

\section{Morphology}

Species of Cronartium may have up to five different spore stages, often referred to by the symbols 0 , I, II, III and IV: 0 = spermatia, I = aeciospores, II = urediniospores, III = teliospores and IV = basidiospores (Kolmer et al. 2009, Voegele et al. 2009, Bergeron et al. 2019). These develop, respectively, in spermogonia, aecia, uredinia, telia, and on basidia (probasidia). They alternate between dikaryotic and haploid nuclear status in both primary (Pinus sp.) and secondary (mostly Ribes sp.) hosts (Kolmer et al. 2009). The typical development of different spore stages are basidiospores (n) and spermatia (n), aeciospores $(n+n)$, urediniospores $(n+n)$ and teliospores $(n+n)$ (Littlefield \& Heath 1979). The different stages of $C$. orientale spores and germinating basidiospore of C. fusiforme are indicated in Fig. 1 (Littlefield \& Heath 1979, Kaneko 2000).

Spermatia, which can be considered as haploid gametes, are produced in spermagonia on pine hosts (Hiratsuka \& Sato 1982). Spermagonia develop between periderm, as flat, yellowish at the beginning, producing spermatia in orange droplets, darkening later, gradually becoming disrupted

because of aecial enlargement (Sullivan 2010). Aecia are peridermioid, dehiscent circumscissile or irregular. Aecial peridium has several thick rhomboid ellipsoid cells that are strongly verrucose (wartlike), with hair like peridial filaments (Sullivan 2010). Cronartium aeciospores are single-celled and thick-walled, the surface of which is covered in small knob-like structures, globose to ovoid-ellipsoid, hyaline (Hansen \& Lewis 1997, Sullivan 2010). Uredinia bear urediniospores on Ribes sp. hosts. Urediniospores are single-celled and darkly pigmented, thick-walled, with germ pores and spine like structures (echinulate). Telia are hypophyllous, often developing in uredinia, and erumpent. Teliospores are produced in chains, adhering in columns to $2 \mathrm{~mm}$ or longer, pale orange to cinnamon brown. Teliospores are ellipsoid to cylindrical, not separating, and smooth, with yellowish wall. They can germinate without dormancy. Usually, upper telial columns have whitish powdery form because of basidia and basidiospores formation (Sullivan 2010). In germination process, teliospores form four-celled promycelium that give rise to basidia and basidiospores (Hansen \& Lewis 1997, Maloy 2003, Liu et al. 2015). Basidia bear basidiospores which produce initial infections on pine species. Mature basidia are septate, four cells, each with a conical protuberance (sterigma).

Basidiospores form at the apex of every sterigma and there are four basidiospores for each basidium. Basidiospores are rounded, smooth, hyaline, and 3-4 $\mu \mathrm{m}$ in diameter (Ragazzi et al. 1987, Sullivan 2010). Basidiospores germinate to produce branched germ tubes, $200 \mu \mathrm{m}$ or more in length, 2-5 $\mu \mathrm{m}$ diameter (Ragazzi et al. 1987, Sullivan 2010). When morphological distinctions are lacking, the host association can be taken as the best identification method for rusts (Hansen \& Lewis 1997).

\section{Life cycle}

Rusts are highly specific organisms showing host specificity (Kolmer et al. 2009). In the heteroecious life cycle, two taxonomically dissimilar hosts (e.g. Pinus and Ribes) are infected as part of the life cycle. The alternation of meiosporic and mitosporic reproduction of the rust pathogens can be seen in two hosts (Taylor et al. 1999). Mostly angiosperms are the primary hosts for Cronartium rusts (Hansen \& Lewis 1997). Scots pine blister rust, C. pini completes its life cycle by alternating between pines and seed-plants of different angiosperm families such as Acanthaceae, Apocynaceae, Balsaminaceae, Gentianaceae, Loasaceae, Orobanchaceae, Paeoniaceae, Papaveraceae, Tropaeolaceae and Verbenaceae (Geils et al. 2009). The life cycle of C. ribicola is shown in (Fig. 2). Cronartium ribicola disease cycle needs many years to complete (Kolmer et al. 2009) and it begins with infection of pine needles by basidiospores. Teliospores, produced in telia in late summer on underside of Ribes leaves, germinate to form basidia that produce basidiospores after meiosis. 

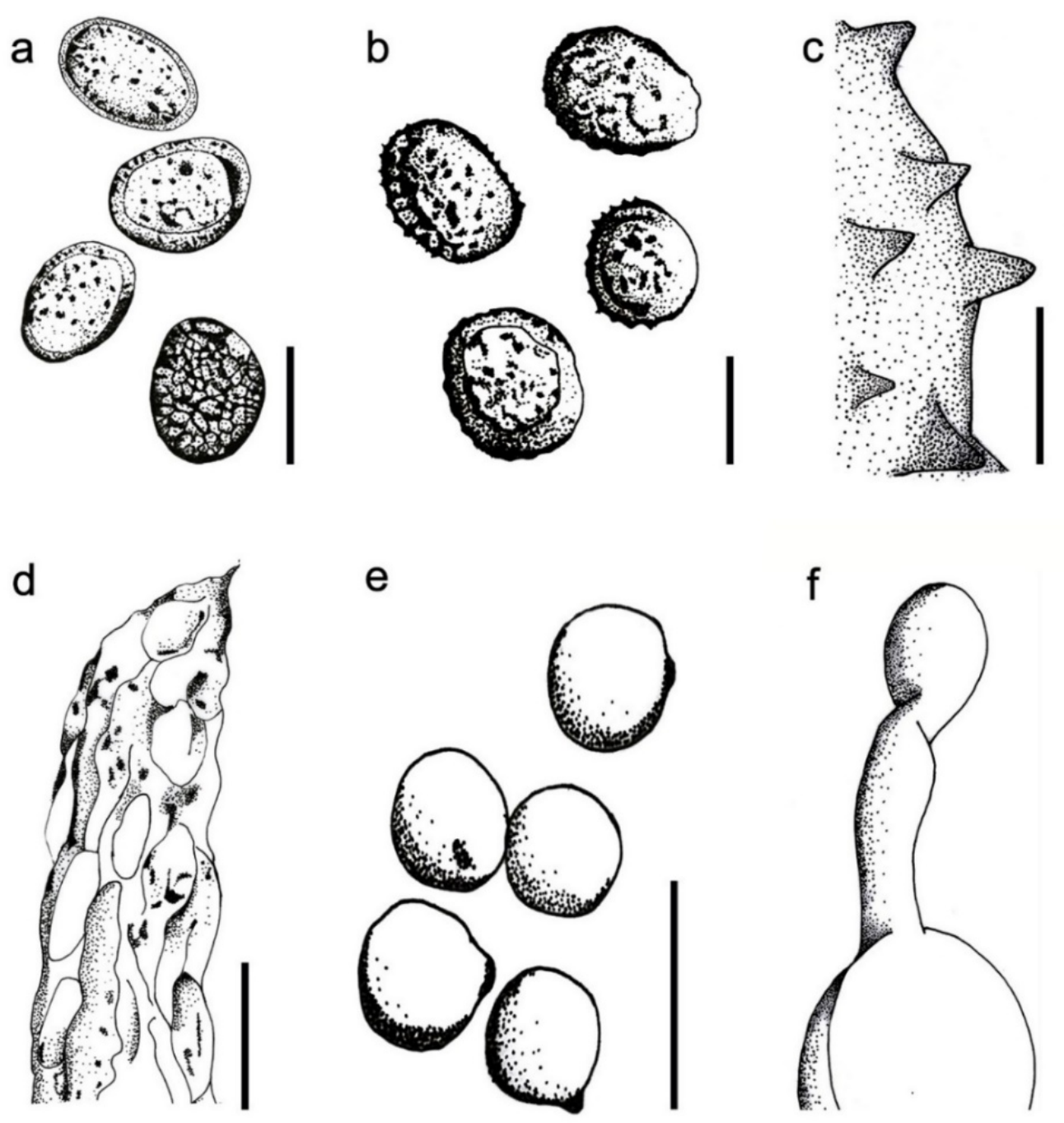

Fig. 1 - Different spore stages of Cronartium orientale (a-e) and germinating basidiospore of $C$. fusiforme (f) redrawn from Littlefield \& Heath (1979) and Kaneko (2000). a Aeciospores on Pinus densiflora. b Urediniospores on Quercus crispula. c SEM view of urediniospore. d Apical part of telial column on $Q$. crispula. e Basidiospores on $Q$. crispula (from fresh teliospores). f Germination of basidiospore with appressorium of Cronartium fusiforme Scale bars: $a-b, e=20 \mu \mathrm{m}, c=5 \mu \mathrm{m}$, $\mathrm{d}=100 \mu \mathrm{m}, \mathrm{f}=\times 2800$.

There are four haploid basidiospores produced from each basidium (Kolmer et al. 2009, Liu et al. 2015). The basidiospores disperse by wind and germinate on pine needles producing a germ tube that penetrates through the stomata (Smith 1970, Maloy 2001, 2003, Kolmer et al. 2009, Liu et al. 2015). For a successful attack viable pathogenic spores and living pine needle with moisture are required (O’Hara et al. 2010). Mycelium that originates from basidiospores grows throughout the pine needles, branches and stems (Lachmund 1933, O’Hara et al. 2010, Liu et al. 2015). Infected needles show disease spots after 4-10 weeks. Base of infected needle bundles are discoloured and become swollen. These swellings on pine base needles, branches and stems develop into cankers, which can exude a large amount of resins (Lachmund 1933, Smith 1970, Maloy 2003). Rapid death of trees may occur after a canker encircles the bole of young five-needle pine tree (Hummer 2000). Cronartium rusts produce spermagonia (pycnia) at canker margins (Maloy 2003, EFSA Panel on Plant Health et al. 2018). Cronartium pini and C. ribicola produce spermogonia in late summer 1-2 years after infection and aecia in the next early summer. These haploid spermagonia contain spermatia (pycniospores) in hypertrophy on host branches, cones and stems (Maier et al. 2003, Kolmer et al. 2009). 


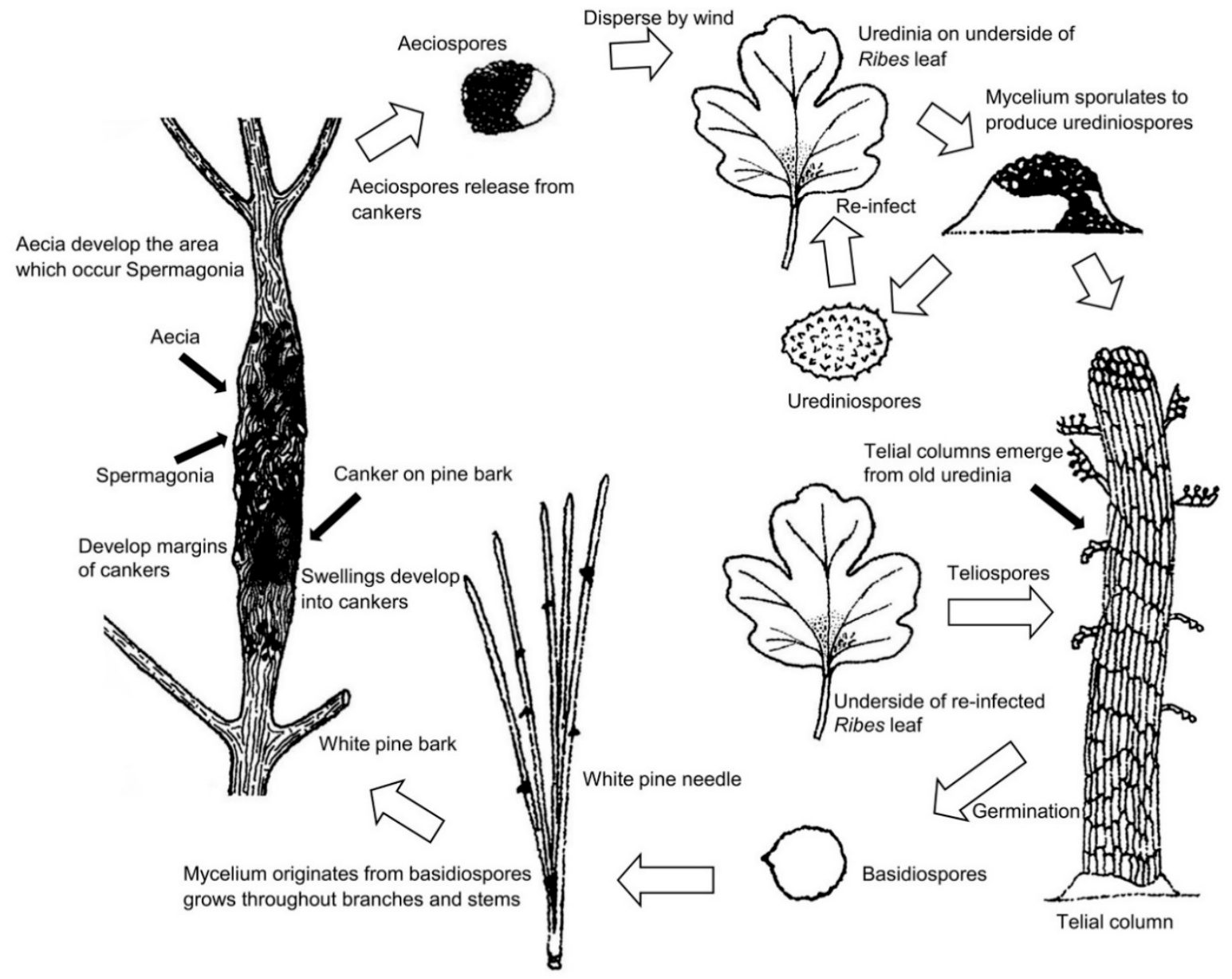

Fig. 2 - Life cycle of Cronartium ribicola redrawn from (Miller et al. 1959).

After plasmogamy, Cronartium rusts produce aeciospores in an aecium which develops at canker regions (Maloy 2003, Kolmer et al. 2009, Ratliff et al. 2015). In spring (or summer at high elevation), aeciospores can emerge through bark of pine trees from the area previously produced spermagonia onto Ribes plants and also Castilleja and Pedicularis species (Kolmer et al. 2009, Liu et al. 2015). Other than wild species aeciospores can disperse artificially on to Bartsia (Orobanchaceae), Euphrasia and Mentzelia (Loasaceae) species. Aeciospores can be dispersed for long distance by wind, as far as $480 \mathrm{~km}$ (Maloy 2003) and after contact with a susceptible host species they germinate, penetrate the stomata and grow rapidly to infect the leaf (Smith 1970, Kolmer et al. 2009). Aeciospores of C. comandrae show optimum germination around $15^{\circ} \mathrm{C}$ when free water and dark environmental conditions are available (Powell 1974). Aecial infection produces cluster type aecial colonies by spreading disease up to death of host (Kolmer et al. 2009). Aecia of $C$. fusiforme induce swelling or galls and C. ribicola aecia induce necrotic cankers (Littlefield \& Heath 1979). Peridermioid aecium is typical of Cronartium spp. The peridium is blister-shaped and has thickwalled cells with several layers covering the whole aecium surface (Littlefield \& Heath 1979, Maier et al. 2003). The mycelium grows through leaves of Ribes sp. and sporulates to produce urediniospores from uredinia over summer (Liu et al. 2015). This stage can repeatedly re-infect the same host throughout summer (Maloy 2003, Kolmer et al. 2009). Urediniospores are transported over short distance (about $1.6 \mathrm{~km}$ ) by wind (Maloy 2003, Richardson et al. 2005). Telial columns, which often develop from the uredinia (Maloy 2003), contain the teliospores. In late summer telia start to produce teliospores in rows (Liu et al. 2015). They germinate in situ to produce basidiospores that are ejected into the air by force but are sensitive to dry conditions (Kolmer et al. 2009). Basidiospores infect the pine host, starting to result in swollen cankers in following spring or summer to complete the life cycle (Kolmer et al. 2009, Liu et al. 2015). The different pathogenic stages, characteristics 
and disease symptoms in life cycle of C. ribicola related aecial host and telial host are summarized in Table 1.

\section{Isolation}

Rusts are obligate biotrophs, which obtain nutrients and survive only on living hosts. Rusts are not lethal to the host until they form and release their spores (Vogler 2008). To study vegetative phases of rust fungi, laboratory practices related to culture preparations are used (Moricca \& Ragazzi 2001). Isolates and growing techniques were reported for single genotype axenic cultures of Cronartium species by single hyphal fragments (Hu et al. 1994, Moricca \& Ragazzi 2001).

Table 1 Different pathogenic stages of Cronartium ribicola.

\begin{tabular}{|c|c|c|}
\hline Pathogenic state & Symptoms and characters & Reference \\
\hline $\begin{array}{l}\text { Spermatia from } \\
\text { spermagonia on } \\
\text { white pine host }\end{array}$ & $\begin{array}{l}\text { Chlorotic spots on pine needles } \\
\text { Yellow-orange color spindle-shaped swollen cankers on pine } \\
\text { branches and stem } \\
\text { Orange color bark at canker margins }\end{array}$ & $\begin{array}{l}\text { Lachmund (1933), } \\
\text { Maloy (2003), } \\
\text { Liu et al. (2015) }\end{array}$ \\
\hline $\begin{array}{l}\text { Aeciospores from } \\
\text { aecia on white } \\
\text { pine host }\end{array}$ & $\begin{array}{l}\text { Aecial blisters on pine host } \\
\text { Yellow-orange aeciospores release from cankers } \\
\text { Dead pine branches and stem (within several years) } \\
\text { Killing all plant parts above the stem } \\
\text { Red colored dead needles from affected branch }\end{array}$ & $\begin{array}{l}\text { Maloy (2003), } \\
\text { O’Hara et al. } \\
\text { (2010), } \\
\text { Liu et al. (2015) }\end{array}$ \\
\hline $\begin{array}{l}\text { Uredinia on Ribes } \\
\text { leaves }\end{array}$ & $\begin{array}{l}\text { Chlorotic (yellow) spots on the upper leaf surface } \\
\text { Orange color uredinia on underside of leaves } \\
\text { Dark brown, hair-like telial column emerge from uredinia }\end{array}$ & $\begin{array}{l}\text { Maloy (2003), } \\
\text { Liu et al. (2015) }\end{array}$ \\
\hline $\begin{array}{l}\text { Telia on Ribes } \\
\text { leaves }\end{array}$ & $\begin{array}{l}\text { Teliospores on underside of leaves } \\
\text { Producing basidia } \\
\text { No infection }\end{array}$ & Maloy (2003) \\
\hline $\begin{array}{l}\text { Basidia on Ribes } \\
\text { leaves }\end{array}$ & Producing basidiospores & $\begin{array}{l}\text { Maloy (2001, } \\
\text { 2003), } \\
\text { Liu et al. (2015) }\end{array}$ \\
\hline
\end{tabular}

Cronartium stem rusts from pine hosts such as C. fusiforme, C. pini, C. quercuum and C. ribicola have been studied for in-vitro growth (Moricca \& Ragazzi 2001). According to Hu et al. (1994) the axenic culture production from C. quercuum f.sp. fusiforme from basidiospores was first reported by Hollis et al. (1972). Successful saprophytic isolates from C. pini using individual basidiospores was first reported by Moricca \& Ragazzi (2001). Previously, the Modified Harvey and Grasham (HG1) and modified Schenk and Hildebrandt (SH1) culture media (Schenk \& Hildebrandt 1972, Harvey \& Grasham 1974) were used for axenic growth of C. pini. Modified HG1 medium (HG1Y) with bovine serum albumin (BSA) has also shown excellent colony growth for singlegenotype axenic cultures (Moricca \& Ragazzi 2001, Moricca \& Ginetti 2015). This culture media has been used to confirm the growth of $C$. pini from aeciospores and basidiospores. However, the capacity for axenic growth of rust fungi from their urediniospores has never been tested (Moricca \& Ginetti 2015).

In isolation process, basidiospores are released onto agar media, showing considerable germination rate. The spores collected in the field can be contaminated with other microorganisms. The single-genotype rust cultures formation in pure culture techniques must overcome this barrier. The low contamination rate should be maintained $(<2 \%)$ by removing the contaminant moulds (Moricca \& Ragazzi 2001). The fungal colony shows fast growth on HG1 and HG1Y media amended with BSA. BSA positively affects fungal growth in media which form comfortable environment to fast hyphal growth (Moricca \& Ragazzi 2001). The pure fungal mycelium can be used for molecularbased investigations for taxonomic development. It is also useful in analysing pathogenic variation. 
Single genotype isolation has high genetic purity than multi-genotype isolation of rust fungi (Moricca \& Ragazzi 2001).

\section{Morpho-molecular studies}

There is taxonomic confusion with white pine blister rusts because of insufficient information about host range and phylogeny (Geils et al. 2010). Spaulding (1922) resolved this and now $C$. ribicola is considered as a single, sexually reproducing rust that alternates between white pines and Ribes (Geils et al. 2010, Schoettle et al. 2019). Previously, Ribes spp. (Grossulariaceae) was considered as the natural alternate hosts of Cronartium ribicola in North America (Zambino et al. 2005). Presently, C. ribicola damage was revealed on wild Castilleja miniata and Pedicularis racemosa (Orobanchaceae) was proved by using ITS rDNA sequence analyses for teliospores while Ribes alternate hosts do not grow in Northern Idaho, USA (Zambino et al. 2005). The first reported molecular analyses of rust fungi were carried out using 5.8S rRNA (Gottschalk \& Blanz 1984, Maier et al. 2003). ITS gene region was selected to confirm closely related species of many genera including Cronartium (Vogler \& Bruns 1998, Maier et al. 2003). Maier et al. (2003) reported the phylogenetic relationships of selected genera in order Uredinales by using nuclear large subunit rDNA data also. Analyzing isozyme patterns and protein arrangements of aeciospores, differences among $C$. appalachianum, C. comandrae, C. harknessii, C. ribicola and C. quercuum can be distinguished (Powers et al. 1989, EFSA Panel on Plant Health et al. 2018).

The relationship between anamorphic Peridermium and Cronartium species was debatable (Vogler \& Bruns 1993, 1998). Peridermium harknessii (anamorphic) species has higher similarities with (teleomorph) C. quercuum complex and C. coleosporioides complex (Vogler \& Bruns 1993, 1998). They were difficult to distinguish using morphology and symptoms on the host. Analysis of ITS sequence results with $P$. harknessii has shown a closer relationship to $C$. quercuum complex than to C. coleosporioides complex and identical to C. quercuum f.sp. banksianae (Vogler \& Bruns 1993). $P$. harknessii was synonymized as Endocronartium harknessii following the cytological evidence (Hiratsuka 1969, Vogler \& Bruns 1993). Vogler \& Bruns (1993) described the close phylogenetic relationships between $P$. harknessii with $C$. quercuum f.sp. banksianae, and $P$. bethelii with $C$. comandra.

The problematic relationship between Cronartium flaccidum and Peridermium pini (currently both known as $C$. pini), has arisen because of different host specificity and some morphological characters related to aeciospores between the two species (Kasanen 2001). Hiratsuka (1968) mentioned that aeciospores of $P$. pini has different aeciospore germ tube morphology in meiosis than C. flaccidum. Kaitera et al. (1999b) measured the morphological variation of aecial germ tubes within populations between above two species. Similar observations in variations of germ tube morphology between C. flaccidum and Peridermium pini have been reported by Klebahn (1938), Gibbs et al. (1988) and Kaitera et al. (1999). However, the studies of the hyphal ultrastructure of $P$. pini in pine cortex by Walles (1974), was compared with ultrastructure of C. flaccidum by Longo (1982) and no differences could be found in septa or haustoria. According to the suggestion from Moricca \& Ragazzi (1998) $P$. pini and C. flaccidum were trying to distinguish by the ITS genes of rDNA (Kasanen 2001). Hantula et al (1998) successfully amplified the random amplified microsatellite (RAMS) markers from both fungi (Kasanen 2001). After phylogenetic analysis some RAMS markers were shown to be co-dominant. These markers are heterozygous within all $C$. flaccidum isolates, while $P$. pini is homozygous. Hantula et al. (1998) mentioned heterozygosity of marker loci of Italian $C$. flaccidum samples also went against to the homozygosity of $P$. pini samples (Kasanen 2001).

Following the molecular analyses, mistakenly identified $C$. coleosporioides were resolved as C. ribicola on Orobanchaceae (Zambino et al. 2005). Another study explored hybrid aecial states between C. comandrae and C. ribicola on limber pine species in British Columbia. By using ITS sequence data from Cronartium teliospores, it was revealed that no hybridization occurs between species on Orobanchaceae hosts (Zambino et al. 2005). Cronartium asclepiadium var. quercuum was the original reported name for pine gall rust disease and Shirai (1899) then synonymized it as $C$. 
quercuum (Kaneko 2000). Morphological studies were done between C. fusiforme and C. quercuum and genetic plasticity has identified to understand the breeding resistivity of Pinus species.

\section{Materials \& Methods}

\section{Molecular data analyzing}

Sequence data for the ITS gene region of Cronartium were obtained (Table 2) from GenBank (National Center for Biotechnology Information) and the literature (Vogler \& Bruns 1993, 1998, Vogler 2008). Single gene alignment was automatically generated from MAFFT v. 7 (https://mafft.cbrc.jp/alignment/server/, Katoh \& Standley 2013). The alignment was improved manually when necessary using BioEdit v. 7.0.9.0 (Hall 1999). Phylogenetic analyses were performed using maximum likelihood (ML) and Bayesian inference (BI). Fifty-nine strains are included in ITS gene region with 702 total characters in the final alignment. Maximum likelihood tree was generated using the RAxML-HPC2 on XSEDE (8.2.8) (Stamatakis 2014) in the CIPRES Science Gateway platform (Miller et al. 2010) using the GTR+I+G model of evolution.

Bayesian analysis was conducted with MrBayes v. 3.1.2 (Huelsenbeck \& Ronquist 2001) to evaluate Bayesian posterior probabilities (BYPP) (Rannala \& Yang 1996, Zhaxybayeva \& Gogarten 2002) by Markov Chain Monte Carlo sampling (BMCMC). GTR $+\mathrm{I}+\mathrm{G}$ was used in the command. Six simultaneous Markov chains were run for 1,000,000 generations and trees were sampled every $100^{\text {th }}$ generation. The distribution of log-likelihood scores was examined to determine stationary phase for each search and to decide if extra runs were required to achieve convergence, using the program Tracer 1.5 (Rambaut \& Drummond 2007). Phylograms were visualized with FigTree v1.4.0 program (Rambaut 2012) and reorganized in Microsoft power point (2010).

\section{Results}

We have constructed a phylogenetic analysis of Cronartium species using ITS locus to show their intra specific relationships (Fig. 3). No topological conflicts occurred between trees generated from ML and BI analyses; the ML tree is shown in Fig. 3 with a final ML optimization likelihood value of -2922.652206. The matrix had 308 distinct alignment patterns, with $12.97 \%$ undetermined characters or gaps. In BI analysis, first $10 \%$ of generated trees were discarded and remaining $90 \%$ of trees were used to calculate posterior probabilities of the majority rule consensus tree. To discuss tree output of the phylogenetic analysis (Fig. 3), we divided the taxa in the phylogram into eight clades $(\mathrm{A}-\mathrm{H})$. In this attempt to illustrate phylogenetic relationships, we observed that there are close phylogenetic affinities from the species those are responsible for specific rust diseases. The species that are reported as causing blister rust diseases, nested in sub clades A, B, D and E. Cronartium appalachianum, C. bethelii, C. coleosporioides, C. comandrae, C. comptoniae, C. pini, C. ribicola and $C$. occidentale were grouped in above sub clades (Fig. 3 ). There is only one known species responsible for limb rust disease (Cronartium arizonicum) and it nested in sub clade $\mathrm{C}$ with close phylogenetic affinity to C. coleosporioides and C. pini. The species responsible for Scots pine blister rust diseases (Cronartium pini) nested in sub clade D with high bootstrap support (100\% ML, 1.00 PP) as a monophyletic group. The species causing gall rust diseases viz. Cronartium harknessii and C. quercuum nested in sub clade F with high bootstrap support (96\% ML, $1.00 \mathrm{PP}$ ) (Fig. 3) as a monophyletic group. The sub clade $\mathrm{F}$ is proven in the literature that anamorphic $C$. harknessii is the teleomorph state of $C$. quercuum reported by Vogler \& Bruns (1993). There are two species reported for causing cone rust disease (C. conigenum and $C$. strobilinum and) and the strains of these species grouped in clade $\mathrm{H}$ as the most basal lineage in our phylogenetic analysis. There are three strains grouped in clade $\mathrm{G}$ that are still not recognized causing any damage to agriculture.

Our choice of ITS as the phylogenetic marker used herein has been based on the availability of ample sequence data. Other gene sequence data are simply not available for almost all of the species. It is recommended to obtain more gene markers such as LSU, RPB2, TEF and tub2 to perform analyses on different combinations of datasets to come up with reliable phylogenies to ensure that species definitions and justifications for establishing new species are scientifically valid in this genus. 


\section{Control of Cronartium diseases}

In North America, chemical control of Cronartium using fungicides is practiced in a large scale, even in nursery stock (Pawsey 1963). High contribution of large-scale planting programs with nursery site selection and disease-free planting stocks should be established to explore the silvicultural potential and pathology of species (Pawsey 1963). Geils et al. (2009) gave general methods to minimize the effect of rust diseases such as fungicides for pine hosts, separation of alternate hosts from pine trees, biological agent for decreasing rust reproduction and silvicultural practices (Geils et al. 2009, Li et al. 2014). Tuberculina maxima the purple mould, has been used as a biological control agent in Western North American white pine blister rust disease (Kimmey 1969, Powell 1971). Tuberculina maxima can restrict aeciospore production of $C$. comandrae and all active cankers on lodge pole pine (Powell 1971). In Europe and Pacific Northwest, T. maxima has been observed and documented with the ability to reduce the inoculum of target rust organisms through inhibition of rust cankers (Maloy 2003). Destroying aeciospores is a promising way to control Armandii pine blister rust in Yunnan, China because of aeciospore generation is important stage which spreads blister rust ( $\mathrm{Li}$ et al. 2014). Li et al. (2014) showed the destructive effect on aeciospores of Armandii pine blister rust by using mycoparasite SS003. Mycoparasite SS003 originally extracted from C. ribicola aeciospore piles and it was identified as Trichoderma atroviride by its morphology and ITS sequence analysis (Zhou et al. 2008, Li et al. 2014). Kaitera (2002) reported that thinning increased growth, and removal of infected Scots pine seeds avoid susceptible seed dispersal and removal of trees reduces disease spread. Consideration of genetic manipulation on selection, breeding, and spreading of hosts with high resistance is needed to mitigate the diseases (Geils et al. 2009). White pine blister rust can be prevented and decreased on young white pine trees by pruning of lower branches (Singleton \& Oblinger 2017). Also, eradication of infected Ribes species is most controllable method for C. ribicola. In China, C. ribicola is a quarantine pest and the control measures are mainly involved with pruning and thinning of infected plants, chemical treatment for blister rust cankers and herbicide removal of telial hosts (Zhang et al. 2010, Li et al. 2014). Continuous investment of pruning treatments can increase survival probability of young white pine (McDonald \& Hoff 2001). Geils et al. (2009) suggested that in North America, high safety policies and diagnostic techniques should be applied to confirm the rust infections for Scots pine blister rust. At the social level, awareness about the diseases and disadvantages to forestry, nursery and horticultural activities and in scientifically, genetic analyses of Scots pine blister rust to predict potential invasive risk should be developed (Geils et al. 2009).

The awareness of density and diversity of rusts on host trees, host populations, communities, and ecosystems are very useful to mitigate their pathogenic impacts (Geils et al. 2009). Regeneration for Resilience (R4R) framework is a powerful management method to control white pine blister rust disease caused by C. ribicola in North America (Schoettle et al. 2019). This is an integrated approach of forest health, genetic resistance, risk and hazard of pathogen and host population (Schoettle et al. 2019). Bulk seeding with qualitative genetic resistant genes is effective in low risk areas. By this, the acceleration of $C$. ribicola virulent strains can be reduced (Schoettle et al. 2019). When the number of healthy trees become too low the population of trees can be increased through regeneration. Also, nutrient-rich sites with susceptible alternate hosts should be avoided in regeneration of pines and deciduous trees can be used as mixture.

Genetic maps are also reported as a successful method to understand disease resistance (Liu et al. 2019). The high-density genetic map was constructed for Pinus flexilis (Limber pine) by exomeseq to understand the evolution of resistance (Liu et al. 2019). The rust resistance orthologous loci and evolutionary pressure on them were revealed by the genetic map (Liu et al. 2019). Genetic mapping has provided a practical tool for breeding and genetic conservation of limber pine and another Pinus sp. (Liu et al. 2019). It is very effective to provide a long-term breeding program on rust resistance against blister rust (Sniezko et al. 2011, Singleton \& Oblinger 2017). Keane et al. (2017) mentioned that the active restoration design which fits the local community is needed for conserving ecosystems of white bark pine. It should be implemented with strategies to effects of climate change as well as considerably reducing the anthropogenic threats (Keane et al. 2017). 


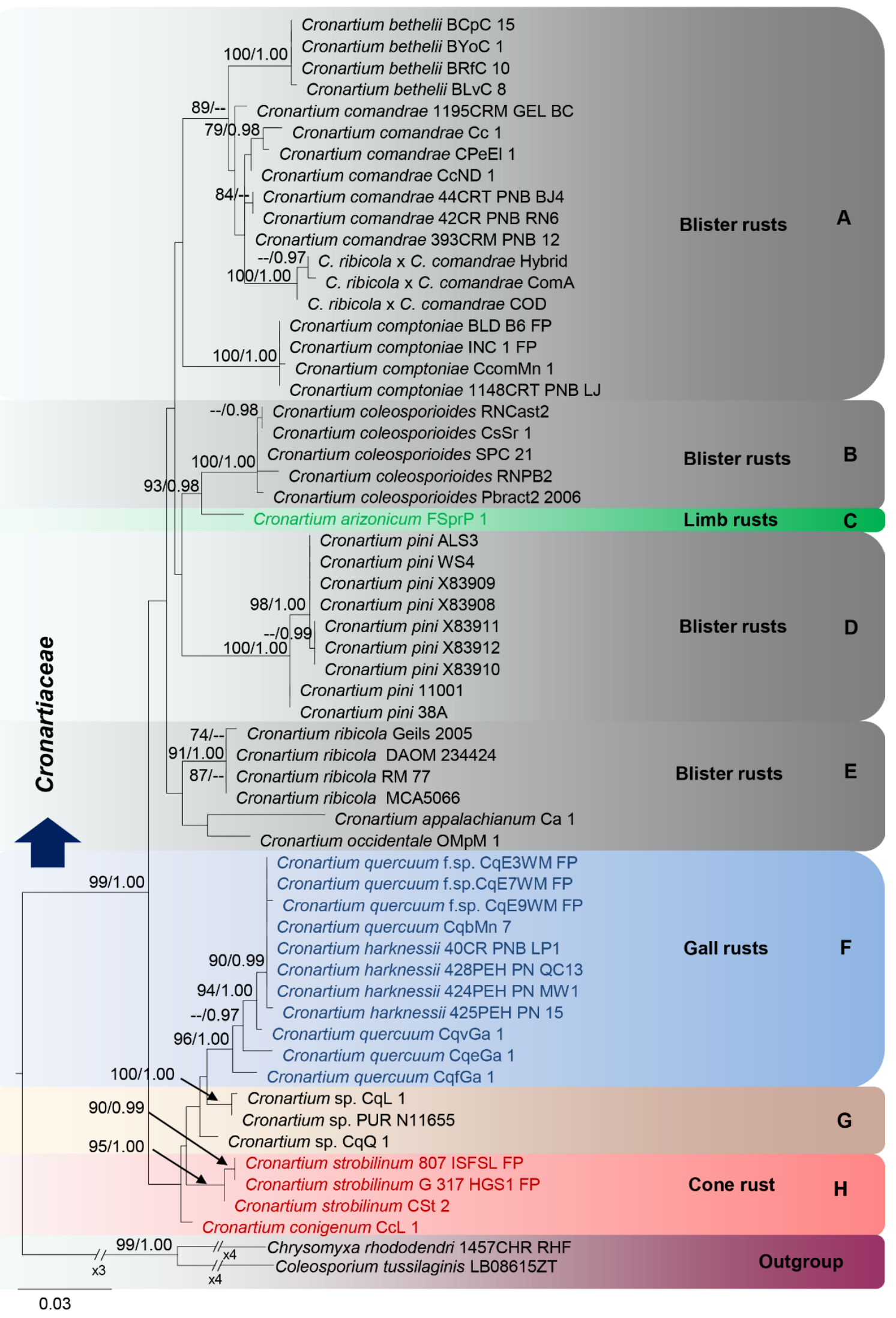

Fig. 3 - RAxML tree based on a dataset of partial ITS sequence analyses (Cronartium). Bootstrap support values for ML equal to or greater than $70 \%$, Bayesian posterior probabilities (PP) equal to or greater than 0.95 are shown as ML/PP above the nodes. The tree is rooted to Coleosporium tussilaginis and Chrysomyxa rhododendri (Coleosporiaceae). The scale bar represents the expected number of nucleotide substitutions per site. Species groups, where known for specific rust diseases are indicated with coloured blocks. 
Table 2 Taxa used for molecular study and their corresponding GenBank numbers.

\begin{tabular}{|c|c|c|}
\hline \multirow{2}{*}{ Species } & \multirow{2}{*}{ Strain/Voucher } & \multirow{2}{*}{$\begin{array}{l}\text { GenBank accessions } \\
\text { ITS }\end{array}$} \\
\hline & & \\
\hline Coleosporium tussilaginis & LB08615/ZT_Myc_57992 & KY810485 \\
\hline Chrysomyxa rhododendri & 1457CHR-RHF-FR/QFB25059 & JF491434 \\
\hline Cronartium appalachianum & Ca-1 & L76484 \\
\hline Cronartium arizonicum & FSprP-1 & L76504 \\
\hline Cronartium bethelii & BYoC-1 & U75987 \\
\hline Cronartium bethelii & BLvC-8 & L76478 \\
\hline Cronartium bethelii & BRfC-10 & L76479 \\
\hline Cronartium bethelii & ВСрС-15 & L76477 \\
\hline Cronartium coleosporioides & Pbract2-2006 & EF185858 \\
\hline Cronartium coleosporioides & RNCast2 & AY955828 \\
\hline Cronartium coleosporioides & RNPB2 & AY955835 \\
\hline Cronartium coleosporioides & SPC-21 & L76513 \\
\hline Cronartium coleosporioides & CsSr-1 & L76500 \\
\hline Cronartium comandrae & 1195CRM-GEL-BC & JN943253 \\
\hline Cronartium comandrae & 393CRM-PNB-X12 & JN943251 \\
\hline Cronartium comandrae & 42CR-PNB-RN6 & JN943242 \\
\hline Cronartium comandrae & 44CRT-PNB-BJ4 & JN943235 \\
\hline Cronartium comandrae & CcND-1 & U75985 \\
\hline Cronartium comandrae & Cc-1 & L76485 \\
\hline Cronartium comandrae & CPeEl-1 & L76481 \\
\hline Cronartium comptoniae & 1148CRT-PNB-LJ & JN943254 \\
\hline Cronartium comptoniae & BLD-B6-FP & JN943209 \\
\hline Cronartium comptoniae & INC-1-FP & JN943208 \\
\hline Cronartium comptoniae & CcomMn-1 & L76487 \\
\hline Cronartium conigenum & CcL-1 & L76486 \\
\hline Cronartium harknessii & 40CR-PNB-LP1 & JN943249 \\
\hline Cronartium harknessii & 424PEH-PN-MW1 & JN943248 \\
\hline Cronartium harknessii & 425PEH-PN-X15 & JN943247 \\
\hline Cronartium harknessii & 428PEH-PN-QC13 & JN943244 \\
\hline Cronartium occidentale & OMpM-1 & L76507 \\
\hline Cronartium pini & GREEK1 & X83908 \\
\hline Cronartium pini & GREEK2 & X83909 \\
\hline Cronartium pini & GREEK3 & X83910 \\
\hline Cronartium pini & THET1 & X83911 \\
\hline Cronartium pini & THET2 & X83912 \\
\hline Cronartium pini & WS4 & KX147063 \\
\hline Cronartium pini & ALS3 & KX147062 \\
\hline Cronartium pini & 11001 & JN802139 \\
\hline Cronartium pini & $38 \mathrm{~A}$ & AY566270 \\
\hline Cronartium quercuum & CqvGa-1 & L76495 \\
\hline Cronartium quercuum & CqbMn-7 & L76492 \\
\hline Cronartium quercuum & CqeGa-1 & L76493 \\
\hline
\end{tabular}


Table 2 Continued.

\begin{tabular}{lll}
\hline \multirow{2}{*}{ Species } & Strain/Voucher & GenBank accessions \\
\cline { 3 - 3 } & & ITS \\
\hline Cronartium quercuum & CqfGa-1 & L76494 \\
Cronartium quercuum f. sp. & CqE3WM-FP & JN943199 \\
Cronartium quercuum f. sp. & CqE7WM-FP & JN943198 \\
Cronartium quercuum f. sp. & CqE9WM-FP & JN943197 \\
Cronartium ribicola & RM-77 & GU727731 \\
Cronartium ribicola & MCA5066 & KF387533 \\
Cronartium ribicola & Geils 2005 & KX574672 \\
Cronartium ribicola & DAOM 234424 & HQ317509 \\
C. ribicola x C. comandrae & HYBRID_ITS_consensus & MG806113 \\
C. ribicola x C. comandrae & COD & MG806112 \\
C. ribicola x C. comandrae & ComA & MG806106 \\
Cronartium sp. & PUR N11655 & KY587788 \\
Cronartium sp. & CqL-1 & L76489 \\
Cronartium sp. & CqQ-1 & L76490 \\
Cronartium strobilinum & G-317-HGS1-FP & JN943192 \\
Cronartium strobilinum & 807-ISFSL-FP & JN943191 \\
Cronartium strobilinum & CSt-2 & L76482 \\
\hline
\end{tabular}

\section{Discussion}

Cronartium species are rust pathogens causing severe damage to conifer forests and to several Ribes species by decreasing plant growth, causing stem deformation, and reducing quality of wood. Applications of natural regeneration using silvicultural practices and artificial regeneration with disease-free plant materials can mitigate this catastrophe. Genetic bottlenecks on pine species should be mitigated by exploring new genetic resistivity probabilities to Cronartium rust diseases for ecosystem balancing with high diversity.

\section{Acknowledgements}

SN Wijesinghe would like to offer her sincere gratitude to Kevin D. Hyde for his valuable suggestions. Wijesinghe also thanks A.R. Rathnayaka, D. Bundhun in Mae Fah Luang University, Thailand and Dr. Udeni Jayalal in Sabaragamuwa University of Sri Lanka for their kind assistance. Dhanushka Wanasinghe would like to thank the CAS President's International Fellowship Initiative (PIFI) for funding his postdoctoral research (number 2019PC0008), the National Science Foundation of China and the Chinese Academy of Sciences for partial financial support under the following grants: 41761144055, 41771063 and Y4ZK111B01.

\section{Accessibility of data}

All the ITS sequence data were extracted from GenBank (Table 2).

\section{References}

Aime MC, Castlebury LA, Abbasi M, Begerow D et al. 2018 - Competing sexual and asexual generic names in Pucciniomycotina and Ustilaginomycotina (Basidiomycota) and recommendations for use. IMA Fungus 30, 75-89.

Allen EA, Blenis PV, HiratsukaY. 1988 - Axenic culture of Endocronartium harknessii. Mycologia 80, 120-123. 
Bergeron MJ, Feau N, Stewart D, Tanguay P, Hamelin RC. 2019 - Genome-enhanced detection and identification of fungal pathogens responsible for pine and poplar rust diseases. PloS One 14, e0210952.

Brar S, Tsui CK, Dhillon B, Bergeron MJ et al. 2015 - Colonization history, host distribution, anthropogenic influence and landscape features shape populations of white pine blister rust, an invasive alien tree pathogen. PloS One 10, p.e0127916.

Cummins G, Hiratsuka Y. 2003 - Illustrated genera of the rust fungi. $3^{\text {rd }}$ ed. St Paul, MN, USA: APS Press.

EFSA Panel on Plant Health, Bragard C, Di Serio F, Gonthier P et al. 2018 - Scientific opinion on the pest categorisation of Cronartium harknessii, Cronartium kurilense and Cronartium sahoanum. EFSA Journal 16, 5511-5443.

Fairweather ML, McMillin J, Rogers T, Conklin D et al. 2006 - Field guide to insects and diseases of Arizona and New Mexico forests In: Stem and Cone Rusts of Pine, Limb Rust, USDA Forest Service, Southwestern Region. pp 164-166.

Fries EM. 1815 - Cronartium. Observationes mycologicae 1, 1-230.

Gäumann E. 1959 - Die Rostpilze Mitteleuropas. Beiträge zur Kryptogamenflora der Schweiz 12, 85-93.

Geils BW, Hummer KE, Hunt RS. 2010 - White pines, Ribes, and blister rust: a review and synthesis. Forest Pathology 40, 147-185.

Geils BW, Klopfenstein NB, Kim MS, Spaine P et al. 2009 - Recovery plan for Scots pine blister rust caused by Cronartium flaccidum and Peridermium pini, Endocronartium pini National Plant Disease Recovery System. Washington, DC: US Department of Agriculture, Agricultural Research Service, Office of Pest Management, 1-24.

Gibbs JN, England N, Wolstenholme R. 1988 - Variation in the pine stem rust fungus Peridermium pini in the United Kingdom. Plant Pathology 37, 45-53.

Gottschalk M, Blanz PA. 1984 - Highly conserved 5S ribosomal RNA sequences in four rust fungi and atypical 5S rRNA secondary structure in Microstroma juglandis. Nucleic Acids Research 12, 3951-3958.

Hall TA. 1999 - BioEdit: a user-friendly biological sequence alignment editor and analysis program for Windows 95/98/NT. In: Nucleic Acids Symposium Series 41, 95-98.

Hamelian RC. 2012 - Tree rusts. In: Gonthier P, Nicolotti G. editors. 2013 Infectious forest diseases, CABI Publishing, Oxford, 547-566.

Hansen EM, Lewis KJ. 1997 - Compendium of conifer diseases. $2^{\text {nd }}$ ed. St. Paul: APS Press, 53-55.

Hantula J, Kasanen R, Kaitera J, Moricca S. 2002 - Analysis of genetic variation suggest that pine rusts Cronartium flaccidum and Peridermium pini belong to the same species. Mycological Research 106, 203-209.

Hantula J. Niemi M, Kaitera J, Jalkanen R et al. 1998 - Genetic variation of pine stem rust in Finland as determined by Random Amplified Microsatellites (RAMS). European Journal of Forest Pathology 28, 361-372.

Harvey AE, Grasham JL. 1974 - Axenic culture of the mononucleate stage of Cronartium ribicola. Phytopathology 64, 1028-1035.

Hiratsuka N, Sato S, Kakishima M, Kaneko S et al. 1992 - The rust flora of Japan. Tsukuba Shuppankai, Ibaraki 26-27.

Hiratsuka Y, Powell JM, Van Sickle GA. 1988 - Impact of pine stem rusts of hard pines in Alberta and the Northwest Territories. Information-Report - Northern Forestry Centre, Canadian Forestry Service 299, 1-9.

Hiratsuka Y, Sato S. 1982 - Morphology and taxonomy of rust fungi. The rust fungi. Edited by Scott KJ, Chakravorty AK. Academic Press, New York, 1-36.

Hiratsuka Y. 1968 - Morphology and cytology of aeciospores and aeciospore germtubes of hostalternative and pine-to-pine races of Cronartium flaccidum in Northern Europe. Canadian Journal of Botany 46, 1119-1122. 
Hiratsuka Y. 1969 - Endocronartium: a new genus for autoecious pine stem rusts. Canadian Journal of Botany 47, 1493-1495.

Hiratsuka Y. 1995 - Pine stem rusts of the world-frame work for a Monograph. Journal of Agricultural Research 14, 1-8.

Hollis CA, Schmidt RA, Kimbrough JW. 1972 - Axenic culture of Cronartium fusiforme. Phytopathology 62, 1417-1419.

Horst RK. 2008 - Plant diseases and their pathogens. Westcott's Plant Disease Handbook, 81-698.

Hu A, Amerson HV, Frampton LJ. 1994 - Isolation and growth of single genotype axenic cultures of Cronartium quercuum f.sp. fusiforme using hyphal fragments from multi-genotype stock colonies. New Forests 8, 299-308.

Huelsenbeck JP, Ronquist F. 2001 - MRBAYES: Bayesian inference of phylogenetic trees. Bioinformatics 17, 754-755.

Hummer KE. 2000 - History of the origin and dispersal of white pine blister rust. HortTechnology 10, 515-517.

Index Fungorum. 2019 - http://www.indexfungorum.org/Names/Names.asp. (Accessed: May 2019).

Jacobi WR, Geils BW, Taylor JE, Zentz WR. 1993 - Predicting the incidence of comandra blister rust on lodgepole pine: site, stand, and alternate-host influences. Phytopathology 83, 630-637.

Jacobi WR, Geils BW, Taylor JE. 2002 - Frequency of comandra blister rust infection episodes on lodgepole pine. Res. Pap. RMRS-RP-36. Fort Collins, CO: U.S. Department of Agriculture, Forest Service, Rocky Mountain Research Station, 36, 1-13.

Kaitera J, Hantula J, Nevalainen S. 2011 - Distribution and frequency of Cronartium flaccidum on Melampyrum spp. in permanent sample plots in Finland. Scandinavian Journal of Forest Research 26, 413-420.

Kaitera J, Hiltunen R, Hantula J. 2015 - Cronartium rust sporulation on hemiparasitic plants. Plant Pathology 64, 738-747.

Kaitera J, Hiltunen R. 2011 - Susceptibilty of Pedicularis spp. to Cronartium ribicola and C. flaccidum in Finland. Forest Pathology 41, 237-242.

Kaitera J, Hiltunen R. 2012 - New alternate hosts for the rusts Cronartium ribicola and Cronartium flaccidum in Finland. Canadian Journal of Forest Research 42, 1661-1668.

Kaitera J, Kauppila T. Hantula J. 2018 - New alternate hosts for Cronartium spp.: Odontites, Euphrasia, Rhinanthus and Papaver. Forest pathology 48, e12466.

Kaitera J, Nuorteva H. 2006 - Susceptibility of Ribes spp. to pine stem rusts in Finland. Forest Pathology 36, 225-246.

Kaitera J, Nuorteva H. 2008 - Inoculations of eight Pinus species with Cronartium and Peridermium stem rusts. Forest Ecology and Management 255, 973-981.

Kaitera J, Seitamäki L, Hantula J, Jalkanen R, Kurkela T. 1999 - Inoculation of known and potential alternate hosts with Peridermium pini and Cronartium flaccidum aeciospores. Mycological Research 103, 235-241.

Kaitera J, Seitamäki L, Hantula J, Jalkanen R, Kurkela T. 1999b - Morphological variation of

Kaitera J. 2002 - Short-term effect of thinning on Pinus sylvestris damage and sporulation caused by Cronartium flaccidum. Scandinavian Journal of Forest Research 17, 158-165.

Kaneko S. 2000 - Cronartium orientale, sp. nov., segregation of the pine gall rust in Eastern Asia from Cronartium quercuum. Mycoscience 41, 115-122.

Kasanen R. 2001 - Relationship between Cronartium flaccidum and Peridermium pini. Academic Dissertation, University of Helsinki. Presentation, p 34.

Katoh K, Standley DM. 2013 - MAFFT multiple sequence alignment software version 7: improvements in performance and usability. Molecular Biology and Evolution 30, 772-780.

Keane RE, Holsinger LM, Mahalovich MF, Tomback DF. 2017 - Restoring white bark pine ecosystems in the face of climate change. Fort Collins, CO, USA: US Department of Agriculture, Forest Service, Rocky Mountain Research Station. General Technical Report. 1123. 
Kimmey JW. 1969 - Inactivation of lethal-type blister rust cankers on western white pine. Journal of Forestry 67, 296-299.

Klebahn H. 1938 - Offene fragen und neue beobachtungen über die rindebewohnenden Blasenroste der Kiefern nebst Bemerkungen über einige andere Rostpilze IX. Zeitschrift für Pflanzenkrankheiten und Pflanzenschütz 48, 369-410.

Kolmer JA, Ordonez ME, Groth JV. 2009 - The rust fungi. In: Encyclopedia of Life Sciences (ELS). John Wiley \& Sons, Ltd: Chichester. 8 p.

Lachmund HG. 1933 - Mode of entrance and periods in the life cycle of Cronartium ribicola on Pinus monticola. Journal of Agricultural Research 47, 791-805.

Leppik EE. 1967 - Phylogeny of rust fungi. Mycologia 59, 568-579.

Leppik EE. 1970 - Gene centers of plants as sources of disease resistance. Annual Review Phytopathology 8, 323-344.

Li J, Yang YH, Zhou L, Cheng LJ et al. 2014 - Destructive effects of a mycoparasite Trichoderma atroviride SS 003 on aeciospores of Cronartium ribicola. Journal of Phytopathology 162, 396401.

Liro JI. 1908 - Uredinae Fennicae [Finnish rust fungi]. Bidrag till Kännedom av Finlands Natur och Folk 65, 1-567.

Littlefield LJ, Heath MC. 1979 - Ultrastructure of rust fungi. Academic press, London, INC, A subsidiary of Hartcourt Brace Jovanovich, Publishers. 1-271.

Liu JJ, Schoettle AW, Sniezko RA, Yao F et al. 2019 - Limber pine (Pinus flexilis James) genetic map constructed by exome-seq provides insight into evolution of disease resistance and a genomic resource for genomics-based breeding. The Plant Journal 98, 745-758.

Liu JJ, Sturrock RN, Sniezko RA, Williams H et al. 2015 - Transcriptome analysis of the white pine blister rust pathogen Cronartium ribicola: de novo assembly, expression profiling, and identification of candidate effectors. Bmc Genomics 16, 678.

Longo N. 1982 - Ultrastructural observations on the septal pore in Cronartium flaccidum (Alb. et

Ma Z, Liu JJ, Zamany A. 2019 - Identification and functional characterization of an effector secreted by Cronartium ribicola. Phytopathology 109, 942-951.

MAFFT v. 6.864b. 2019 - http://mafft.cbrc.jp/alignment/server/index.html, (Accessed August 2019).

Maier W, Begerow D, Weiß M, Oberwinkler F. 2003 - Phylogeny of the rust fungi: an approach using nuclear large subunit ribosomal DNA sequences. Canadian Journal of Botany 81, 12-23.

Maloy OC. 2001 - White pine blister rust. Online. Plant Health Progress. Doi: 10.1094/PHP20010924-01-HM.

Maloy OC. 2003 - White pine blister rust: symptoms and signs. The Plant Health Instructor. Doi: 10.1094/PHI-I-2003-0908-01.

McDonald GI, Hoff RJ. 2001 - Blister rust: An introduced plague, Whitebark Pine Communities: Ecology and Restoration. Eds. Tomback DF, Arno SF, Keane RE. Island Press, Washington, DC, 193-220.

Millar CI, Kinloch BB. 1989 - Taxonomy and phylogeny and coevolution of pines and their stem rusts. In: Hiratsuka Y, Samoil JK, Blenis PV, Crane PE, Laishley BL. editors. 1991. Rusts of Pine. Proc. 3rd IUFRO Rusts of Pine Working Party Conference, Banff, Alberta. For.Can, Northwest Reg., North. For. Cent., Edmonton, Alberta. Inf. Rep. NOR-X-317: p. 1-38.

Miller DR, Kimmey JW, Fowler ME. 1959 - White pine blister rust. Forest Pest Leaflet 36. USDA Forest Service; Washington, D.C. 8 p.

Miller MA, Pfeiffer W, Schwartz T. 2010 - Creating the CIPRES Science Gateway for inference of large phylogenetic trees. In: Proceedings of the gateway computing environments workshop (GCE). Institute of Electrical and Electronics Engineers, New Orleans, LA, 14 Nov, pp 1-8.

Mordue JEM, Gibson IAS. 1978 - Cronartium flaccidum. CMI Descriptions of Pathogenic Fungi and Bacteria. No. 680.

Moricca S, Ginetti B. 2015 - Saprophytic growth of the alder rust fungus Melampsoridium hiratsukanum on artificial media. Fungal Biology 119, 568-579. 
Moricca S, Ragazzi A. 1998 - Use of RFLP and SSCP analysis to differentiate the pine rusts Cronartium flaccidum and Peridermium pini. Mycological Research 102, 666-670.

Moricca S, Ragazzi A. 2001 - Establishment of single-genotype axenic cultures from the haploid stage of the pine blister rust Cronartium flaccidum. Mycological Research 105, 1527-1532.

Moriondo F. 1975 - Caratteristiche epidemiche della ruggine vescicolosa del Pino: Cronartium flaccidum (Alb. et Schw.) Wint in Italia. Annales Accademia Italiana di Scienze Forestali 24, 331-406.

Nevill RJ, Lam F, Merler H, Borden JH. 1990 - Effects of atropellis canker and stalactiform blister rust on the bending strength and stiffness of lodgepole pine lumber. Wood Science and Technology 24, 225-232.

O’Hara K, Grand L, Whitcomb A. 2010 - Pruning reduces blister rust in sugar pine with minimal effects on tree growth. California Agriculture 64, 31-36.

Pawsey RG. 1963 - A reappraisal of the importance of Cronartium ribicola on Pinus strobus in Great Britain. Forestry: An International Journal of Forest Research 36, 219-226.

Pawsey RG. 1974 - Cronartium comptoniae, a Potential Threat to Pinus contorta in Britain. Forestry: An International Journal of Forest Research 47, 89-91.

Peridermium pini and Cronartium flaccidum aeciospores. Mycological Research 103, 677683.

Peterson RS. 1973 - Studies of Cronartium (Uredinales). Reports of the Tottori Mycological Institute 10, 203-223.

Powell J. 1971 - Incidence and effect of Tuberculina maxima on cankers of the pine stem rust, Cronartium comandrae. Phytoprotection 52, 104-111.

Powell J. 1974 - Environmental factors affecting germination of Cronartium comandrae aeciospores. Canadian Journal of Botany 52, 659-667.

Powers HR, Lin D, Hubbes M. 1989 - Interspecific and intraspecific differentiation within the genus Cronartium by isozyme and protein pattern analysis. Plant Disease 73, 691-694.

Powers HRJ. 1982 - Pathogenic variability within the genus Cronartium. Proceeding Resistance to diseases and pests in forest trees. Eds. Heybroek HM, Stephan BR, Weissenberg KV. Wageningen, the Netherlands pp. 236-242.

Ragazzi A, Fagnani A, Fedi ID. 1987 - Telial and basidiospore stages of Cronartium flaccidum: light and scanning electron microscopy observations. Phytopathologia Mediterranea 26, 113-116.

Rambaut A, Drummond AJ. 2007 - Tracer v1, 4. Available from: http://beast.bio.ed.ac.uk/Tracer.

Rambaut A. 2012 - FigTree version 1.4.0. Available at http://tree.bio.ed.ac.uk/software/figtree.

Rannala B, Yang Z. 1996 - Probability distribution of molecular evolutionary trees: a new method of phylogenetic inference. Journal of Molecular Evolution 43, 304-311.

Ratliff WS, Walker ES, Levy F. 2015 - Demographics and Cronartium appalachianum rust disease assessments in three Tennessee populations of Buckleya distichophylla (Nutt.) Torr. (Santalaceae). Castanea 80, 243-252.

Reich RW, John S. 2018 - Ten-year results of a Comandra blister rust screening trial in the central interior of British Columbia. In: Schoettle AW, Sniezko RA, Kliejunas JT, eds. Proceedings of the IUFRO joint conference: Genetics of five-needle pines, rusts of forest trees, and Strobusphere, 2014 June 15-20, Fort Collins, CO. Proc. RMRS-P-76. Fort Collins, CO: US Department of Agriculture, Forest Service, Rocky Mountain Research Station 76,118-123.

Richardson B, Klopfenstein NB, Peever TL. 2005 - Assessing forest-pathogen interactions at the population level. Forest Pathology from Genes to Landscapes. Ed. By Lundquist JE, Hamelin RC. St. Paul, MN: American Phytopathology Society Press 21-30.

Schenk RU, Hildebrandt AC. 1972 - Medium and technique for induction and growth of monocotyledonous and dicotyledonous plant cell cultures. Canadian Journal of Botany 50, 199-204.

Schoettle AW, Burns KS, Cleaver CM, Connor JJ. 2019 - Proactive Limber Pine Conservation Strategy for the Greater Rocky Mountain National Park Area. Gen. Tech. Rep. RMRS-GTR- 
379. Fort Collins, CO: US Department of Agriculture, Forest Service, Rocky Mountain Research Station. 81, 379.

Schw.) Wint. also in relation to the taxonomy of the Uredinales. Caryologia 35, 425-441.

Shirai M. 1899 - "On the genetic connection between Peridermium giganteum (Mayr) Tubeuf1) and Cronartium quercuum (Cooke) Miyabe.” Shokubutsugaku Zasshi 13, 74-79.

Singleton R, Oblinger BW. 2017 - Prioritizing young western white pine stands for blister rust pruning on the Warm Springs Reservation. Journal of Forestry 115, 385-392.

Smeltzer DL, French DW. 1981 - Factors affecting spread of Cronartium comptoniae on the sweetfern host. Canadian Journal of Forest Research 11, 401-409.

Smith WH ed. 1970 - Fungi that cause various symptoms, In; Tree pathology: a short introduction. The mechanism and control of pathological stress of forest trees. Academic Press. New York and London. 186-197.

Sniezko RA, Mahalovich MF, Schoettle AW, Vogler DR. 2011 - Past and current investigations of the genetic resistance to Cronartium ribicola in high-elevation five-needle pines. In: Keane RE, Tomback DF, MurraYMP, Smith CM. eds. The future of high-elevation, five-needle white pines in Western North America: Proceedings of the High Five Symposium. 28-30 June 2010, Missoula, MT. Proceedings RMRS-P-63. Fort Collins, CO: US Department of Agriculture, Forest Service, Rocky Mountain Research Station 63, 246-264.

Sniezko RA, Smith J, Liu JJ, Hamelin RC. 2014 - Genetic resistance to fusiform rust in southern pines and white pine blister rust in white pines - a contrasting tale of two rust pathosystemscurrent status and future prospects. Forests 5, 2050-2083.

Spaulding P. 1922 - Investigations of the white-pine blister rust. Bull. 957. Washington, DC: U.S. Department of Agriculture, Forest Service. Rocky Mountain Research Station. Citeseer 246264.

Spaulding PC. 1929 - White pine blister rust: A comparison of European with North American conditions. United States Department of Agriculture Technical Bulletin 87, 58.

Species Fungorum. 2019 - http://www.speciesfungorum.org/Names/Names.asp. (Accessed: May 2019).

Stamatakis A. 2014 - RAxML version 8: a tool for phylogenetic analysis and post-analysis of large phylogenies. Bioinformatics 30, 1312-1313.

Stewart FC. 1906 - An outbreak of the European currant rust (Cronartium ribicola Dietr.) New York (Geneva) Agricultural Experiment Station Technical Bulletin 2, 61-74.

Sullivan M. 2010 - CPHST Pest Datasheet for Cronartium flaccidum. USDAAPHISPPQ-CPHST. Revised July 2015 by D. Z. Mackesy.

Sydow P, Sydow H. 1915 - "Monographia Uredinearum,vol 3 Pucciniaceae." Melampsoraceae Zaghouaniaceae-Coleosporiaceae. Fratres Borntraeger, Leipzig. 334-350.

Taylor J, Jacobson D, Fisher M. 1999 - The evolution of asexual fungi: reproduction, speciation and classification. Annual Review of Phytopathology 37, 197-246.

Van der Kamp BJ. 1994 - Lodgepole pine stem diseases and management of stand density in the British Columbia interior. Forestry Chronicle 70, 773-779.

Voegele RT, Hahn M, Mendgen K. 2009 - The Uredinales: Cytology, biochemistry, and molecular biology. Plant Relationships 69-98.

Vogler DR, Bruns TD. 1993 - Use of molecular characters to identify holomorphs: an example from the rust genus Cronartium. The Fungal Holomorph: mitotic, meiotic and pleomorphic speciation in fungal systematics 237-245.

Vogler DR, Bruns TD. 1998 - Phylogenetic relationships among the pine stem rust fungi (Cronartium and Peridermium spp.). Mycologia 90, 244-257.

Vogler DR. 2008 - The Pine-Oak Rusts: How Forest Tree Species Connect. International Oaks 19, 67-76.

Walles B. 1974 - Ultrastructure of the rust fungus Peridermium pini (Pers.) Lev. Studia forestalia Suecica 122, 1-30. 
Zambino PJ, Richardson BA, Mcdonald GI, Klopfenstein NB, Kim MS. 2005 - "A paradigm shift for white pine blister rust: non-Ribes alternate hosts of Cronartium ribicola in North America". In: Guyon JC, comp. Proceedings of the Fifty-Third Western International Forest Disease Work Conference, 26-29 August 2005, Jackson WY, Ogden UT. US Department of Agriculture, Forest Service, Intermountain Region 161-163.

Zhang XY, Lu Q, Sniezko RA, Song RQ, Man G. 2010 - Blister rusts in China: hosts, pathogens, and management. Forest Pathology 40, 369-381.

Zhaxybayeva O, Gogarten JP. 2002 - Bootstrap, Bayesian probability and maximum likelihood mapping: exploring new tools for comparative genome analyses. BMC Genomics 3, 4.

Zhou L, Li J, Chen YH, Li YH. 2008 - Morphologic identification ITS and sequence analysis of 3 hyperparasitism Trichoderma strains Cronartium ribicola J. C. Fischer. Journal of Anhui Agricultural Sciences 36, 6211-6213.

Zuluaga CP, Buriticá P, Marin MR. 2011 - Phylogenetic analysis of rust fungi (Uredinales) from the Colombian Andean region using 28S ribosomal DNA sequences. Revista de Biologia Tropical 59, 517-540. 